\title{
Electroflotation Applied to the Treatment of Wastewaters Containing Chlorimuron-Ethyl, a Sulfonylurea Herbicide
}

\author{
Ramom Rachide Nunes*, Gabriel Muniz Morão, Maria Olímpia Oliveira \\ Instituto de Química de São Carlos, Universidade de São Paulo, São Carlos, Brazil \\ Email: rachide@iqsc.usp.br
}

Received 3 May 2015; accepted 22 May 2015; published 28 May 2015

Copyright (C) 2015 by authors and OALib.

This work is licensed under the Creative Commons Attribution International License (CC BY).

http://creativecommons.org/licenses/by/4.0/

(c) (i) Open Access

\section{Abstract}

Electroflotation (EF) is an electroanalytical technique commonly used for the separation of substances suspended in an aqueous phase. However, these studies are limited to the separation of wastes or contaminants, without destroying the contaminants. In this study, EF was applied as an advanced oxidation process, aiming to decontaminate wastewater containing sulfonylurea herbicides (chlorimuron-ethyl). Electroflotations were performed in an electroflotator reactor developed in the Laboratory of Environmental Chemistry, Institute of Chemistry of São Carlos, University of São Paulo, Brazil. The reactor was built in acrylic and was provided with aluminium electrodes. In addition, the anion electrode also was an agitation bar, that ensured the homogeneity of the solution during the process. Four assays were performed with varying salt concentrations (electrolyte- $\mathrm{NaCl}$ ) and a direct electric current (I) was applied through the electrodes. Chemical monitoring was performed to determine the efficiency of the electrochemical process. Analysis of water samples by HPLC allowed the electrochemical reaction to be monitored, indicating a disturbance of the reaction medium (presence of byproducts of degradation). Gas chromatography coupled with mass spectrometry (GC-MS) was used to elucidate the mechanism of degradation and assist in the identification of the byproducts. According to the chromatograms obtained by HPLC-UV, the $E F$ process changed the reaction medium, resulting in a displacement of the herbicide chromatographic peak and the appearance of bands without defined structure, related to the by-products generated/Based on the mass spectrum obtained, a mechanism of degradation was proposed, showing that EF does not totally destroy the chlorimuron-ethyl molecule, but it was successful in breaking important chemical bonds, responsible for the connection sulfonyl-urea. This study provides important information about the possibility of promoting the oxidation of toxic organic compounds by electroflotation, to generate less toxic and better environmentally adjusted effluents.

\section{Keywords}

Electroflotation, Sulfonylurea, Chlorimuron-Ethyl, Chromatography

\footnotetext{
${ }^{*}$ Corresponding author.

How to cite this paper: Nunes, R.R., Morão, G.M. and Rezende, M.O.O. (2015) Electroflotation Applied to the Treatment of Wastewaters Containing Chlorimuron-Ethyl, a Sulfonylurea Herbicide. Open Access Library Journal, 2: e1540.

http://dx.doi.org/10.4236/oalib.1101540
} 


\section{Subject Areas: Environmental Sciences}

\section{Introduction}

Sulfonylureas are a relatively recent group of herbicides used essentially on cereal crops. Developed in 1975 by the DuPont ${ }^{\circledR}$ Company, the first commercially synthesized sulfonylurea was released in 1981 . At present, $12 \%$ of the global herbicide market belongs to the sulfonylurea chemical group, which ranks second in the industry. There is little information about the consumption of these herbicides throughout the world, but it is known that in the United States, sulfonylureas are applied to more than 150 million hectares, totaling US\$ 1.5 billion in sales per year [1].

Due to their low application rates $\left(10-50 \mathrm{~g} \cdot \mathrm{ha}^{-1}\right)$, low mammalian toxicity, and high herbicidal activity, this group of herbicides is of considerable interest to agronomists and farmers in the whole world. The molecular structure of a sulfonylurea is based on the general formula $\mathrm{R}_{1}-\mathrm{SO}_{2}-\mathrm{NH}-\mathrm{CO}-\mathrm{NH}-\mathrm{R}_{2}$, where the $\mathrm{R}_{1}$ group can be an aliphatic chain, an aromatic, or a heterocyclic moiety connected by the sulfonylurea bridge to a pyrimidine or triazine heterocyclic (the $\mathrm{R}_{2}$ moiety) [2].

Chlorimuron-ethyl (Figure 1) is a sulfonylurea herbicide of which the formulation is one of the most widely marketed, and is commonly used in the control of weeds in cereal and grain crops. In Brazil this herbicide is one of those contributing to the high rate of national soybean production, the main Brazilian agricultural product for export [1].

Pesticide overuse is a reason for concern, as well as the industrial production of herbicides, which results in the production of contaminated wastewaters. In order to protect the environment and its inhabitants, these wastewaters require adequate treatment before their disposal in natural watercourses. Effluents contaminated by herbicides generally present concentrations above those allowed by current environmental laws, as well as toxicity levels too high for the application of biological treatments [3]. The necessity to reduce the environmental impacts caused by this wastewater has been a motivating factor to develop effective methods for the degradation of pesticides in effluents [4]. In this study, we present electroflotation (EF) as an alternative to be applied in the treatment of wastewaters containing herbicides in solution.

Electroflotation (EF) is a technique that consists in the use of hydrogen and oxygen bubbles to perform the separation of suspended substances from aqueous phases. EF has many advantages compared with others conventional oxidation processes, including high flotation efficiency, compact units, easy operation, and less maintenance. This technique has proven very effective in treating oily wastewater or oil-water emulsions, mining wastewater, groundwater, food processing wastewater, restaurant wastewater, industrial sewage, effluent containing heavy metals, and many other types of water and wastewater [5].

An EF reactor has sacrificial eleetrodes of aluminium (Al), which generate $\mathrm{Al}^{+3}$ ions due to the application of an electric potential Electrodes of iron $\left(\mathrm{Fe} \mid \mathrm{Fe}^{+3}\right)$ may also be used. This step is part of the anode process whereby the aluminun metal is oxidized (Reaction 1). The cation generated in the anode step is hydrolyzed to form the coagulating agent $\mathrm{Al}(\mathrm{OH})_{3}$, which will be responsible for coagulation and the formation of colloidal particles (Reactions 2-4) [6].

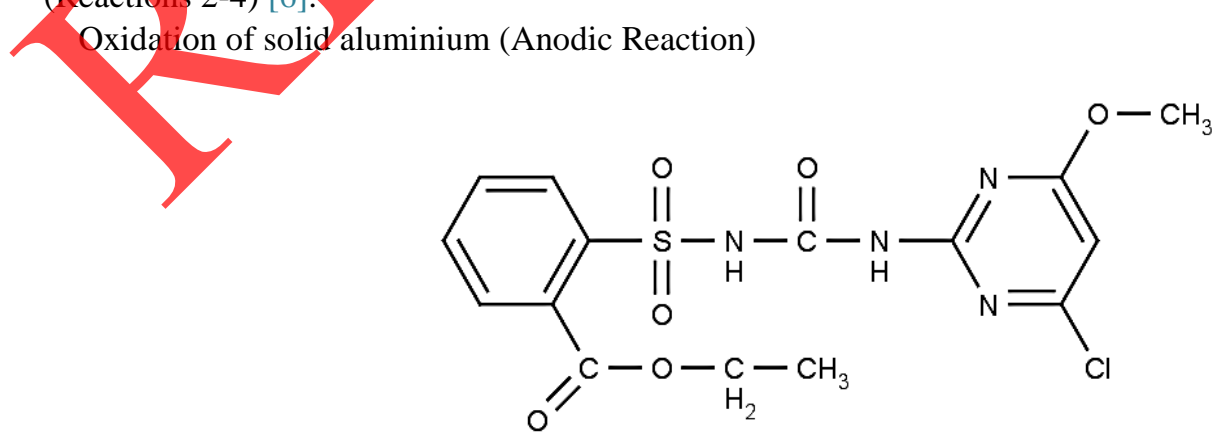

Figure 1. Chemical structure of the chlorimuron-ethyl, the sulfonylurea herbicide studied in this paper. 


$$
\mathrm{Al} \rightarrow \mathrm{Al}^{3+}+3 \mathrm{e}^{-}
$$

Reaction (1)

Solvation of the cation formed

$$
\mathrm{Al}^{3+}+6 \mathrm{H}_{2} \mathrm{O} \rightarrow \mathrm{Al}\left(\mathrm{H}_{2} \mathrm{O}\right)_{6}^{3+}
$$

Formation of coagulant agent

$$
\mathrm{Al}\left(\mathrm{H}_{2} \mathrm{O}\right)_{6}^{3+} \rightarrow \mathrm{Al}(\mathrm{OH})_{3 \downarrow}+3 \mathrm{H}^{+}
$$

Secondary reactions

$$
n \mathrm{Al}(\mathrm{OH})_{3} \rightarrow \mathrm{Al}_{n}(\mathrm{OH})_{3 n \downarrow}
$$

Reaction 4 leads to the formation of various aluminium complexes that are responsible for the removal of contaminants. The larger aluminium clots originated are responsible for the adsorption of the particles resulting from the incomplete mineralization of the herbicide or its oxidation into degradation byproducts, and thus allows for the removal of these molecules from the system [6].

After obtaining a satisfactory yield and adapting the electroanalytical process with regard to the environmental laws, the effluent from a pesticide industry source forms a new effluent, which in theory will be free from pollution load or toxic degradation byproducts [7].

To evaluate and monitor the quality of water bodies, various analytical techniques have been used in the isolation and quantification of pesticides. Among these, chromatography has been employed in the quantitation of herbicides and their metabolites in environmental matrices soil, water, sediments, etc. [8]. In addition, based on previous studies, gas chromatography coupled with mass spectrometry (GC-MS) has been used to elucidate mechanisms of degradation.

Therefore, the present study aimed to apply electroflotation as a treatment of wastewaters containing chlorimuron-ethyl, a compound of the sulfonylurea herbicide group. The process was monitored by HPLC-UV and a mechanism of degradation proposed, assessed by GC-MS.

\section{Materials and Methods}

\subsection{Electroflotation}

Electroflotation experiments were performed in an electroflotator reactor (Figure 2) developed in the Laboratory of Environmental Chemistry, São Carlos Institute of Chemistry, University of São Paulo, Brazil.

The electroflotator reactor had $0.50 \mathrm{~L}$ capacity and was equipped with six aluminium electrodes (cathodes) with dimensions of $7.00 \times 4.00 \times 0.25 \mathrm{~cm}$ (length $\times$ width $\times$ wall thickness) and $1.0 \mathrm{~cm}$ distance between them.

The agitation system using an aluminium bar was a special feature of this reactor. Agitation ensured the homogeneity of the solution during electroflotation and, furthermore, the aluminium bar acted as an electrode

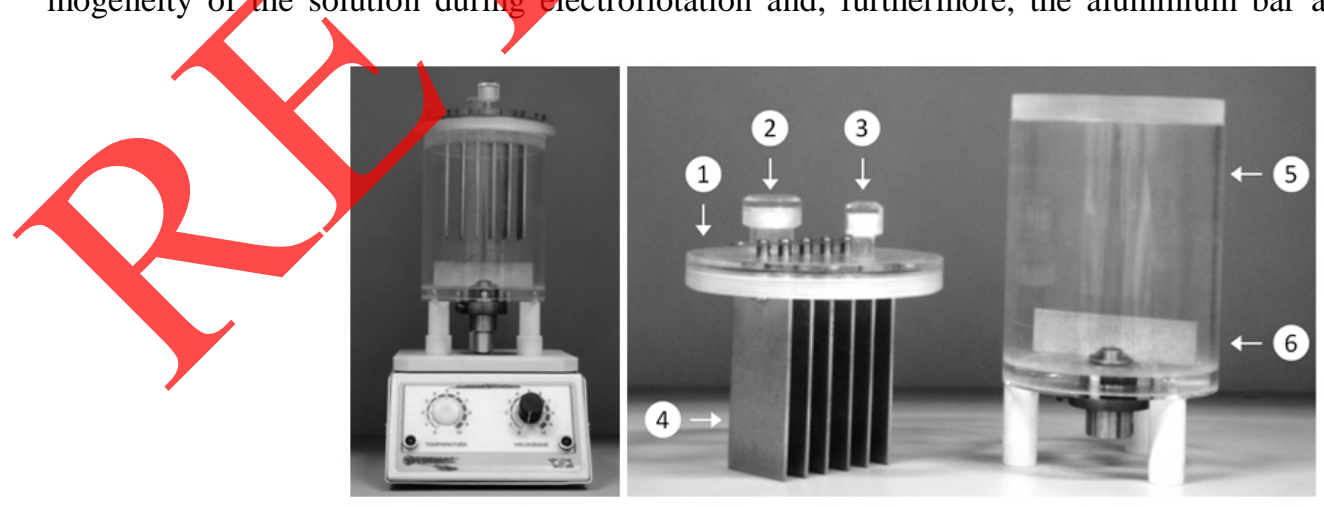

Figure 2. Electroflotator reactor used in the chemical treatment of the herbicide chlorimuron-ethyl under different conditions and electrochemical parameters. (1) Acrylic cover; (2) Sample collection point; (3) Control of air and temperature; (4) Aluminium electrodes (cathode); (5) Acrylic container; (6) Aluminium electrode used for agitation (anode). 
(anode) of the electroanalytical process.

Tests were performed in a solution of chlorimuron-ethyl (CAS 90982-32-4) (Sigma-Aldrich, Germany), with concentration $1.0 \mathrm{mg} \cdot \mathrm{L}^{-1}$. Four assays were executed, varying the salt concentration $(\mathrm{NaCl})$ in the solution and the direct electric current (I) applied on the electrodes (Table 1). Conditions and parameters analysed were based on published works [9] [10].

\subsection{Chemical Efficacy Monitoring}

\subsubsection{Sample Collection}

Through the sample collection point, placed on the acrylic cover, $10 \mathrm{~mL}$ of sample were collected at the times 0 , 30, 60, 120 and $180 \mathrm{~min}$. For that, an automatic pipette was used and the liquid put into a glass flask. Samples were bubbled with nitrogen and stored in a freezer at $-5^{\circ} \mathrm{C}$.

\subsubsection{Herbicide Degradation}

High Performance Liquid Chromatography with an ultraviolet detector (HPLC-UV) (Shimadzu SCL 10A model with a UV-Vis SPD-20A detector, Japan) was used to monitor the areas under the chromatographic peaks related with the herbicide chlorimuron-ethyl. A chromatography column RP18-5 un $\times 250 \mathrm{~mm} \times 4.6 \mathrm{~mm}$ (Agilent Zorbax, United States) was used for the determinations. Chromatography parameters utilized were: mobile phase composition $=60 \% \mathrm{ACN}+40 \%$ (solution of $\mathrm{H}_{3} \mathrm{PO}_{4} 1 \%$ ), nobile phase flow $=1.4 \mathrm{~mL} \cdot \mathrm{min}^{-1}$ (isocratic elution), temperature $=25^{\circ} \mathrm{C}$, duration $=5 \mathrm{~min}$, manual injection $(20 \mu \mathrm{L})$. These parameters were chosen through preliminary tests.

\subsubsection{Degradation Products}

Gas chromatography coupled with mass spectrometry (GC-MS) (Shimadzu GC-2010 MS QP2010 Plus model, Japan) was used to identify degradation byproducts. The MS had a high resolution HP5 capillary column of dimensions $0.25 \mu \mathrm{m} \times 30 \mathrm{~m} \times 0.25 \mathrm{~mm}$. Chromatography parameters utilized were: mobile phase $=$ helium gas (He), total mobile phase flow $=15 \mathrm{~mL} \cdot \mathrm{min}^{-1}$, column flow $=2 \mathrm{~mL} \cdot \mathrm{min}^{-1}$, heating ramp $=0^{\circ} \mathrm{C}$ to $270^{\circ} \mathrm{C}$ with heating rate of $28.8^{\circ} \mathrm{C}$ per minute. Approximately $5 \mathrm{~mL}$ were analyzed by headspace with automatic injection. These parameters were chosen through preliminary tests.

\subsubsection{Residual Aluminium $\left(\mathrm{A}^{(3+}\right)$}

To determine the amount of aluminiun released by the passive electrodes during electroflotation, atomic adsorption spectroscopy by induced plasma was used. Specifically, a Plasma Emission Spectrometer (Inductively Coupled Plasma/ICP) Perkin Elmer/Optima 3000DV (Wellesley, USA) operating on a standard mode of analysis was used. Results obtained were compared with Brazilian [11] and international legislation: US-EPA [12] and EU-Environment:[13].

\section{Results and Discussion}

\subsection{Residual Auminitum}

The results of ICP analyses indicated a different content of residual aluminium in the wastewaters obtained after the treatment by electroflotation (Table 2).

Different values of dissolved aluminium were due to the reaction conditions applied in each assay. The A3 treatment resulted in the lowest aluminium content, probably due to the softer reaction conditions (low electric

Table 1. Assays performed to determine the optimal electrochemical parameters to degrade the herbicide, varying the electric current (I) and the salt concentration $[\mathrm{NaCl}]$.

\begin{tabular}{ccc}
\hline Assays & Electric current (I)/A & {$[\mathrm{NaCl}] / \mathrm{mg} \cdot \mathrm{L}^{-1}$} \\
\hline A1 & 1.50 & 0.25 \\
A2 & 1.50 & 0.50 \\
A3 & 1.00 & 0.25 \\
A4 & 1.00 & 0.50 \\
\hline
\end{tabular}


Table 2. Aluminum content in the wastewater treated by electroflotation and comparison with different international environmental law: European Union, US-EPA and Brazil-CONAMA.

\begin{tabular}{cccc}
\hline Assays & {$[\mathrm{Al}] / \mathrm{mg} \cdot \mathrm{L}^{-1}$} & Legislation & Max. Permitted $/ \mathrm{mg}^{*} \mathrm{~L}^{-1}$ \\
\hline A1 & $0.22 \pm 0.01 \mathrm{~b}$ & Brazil-CONAMA [11] & 0.20 \\
A2 & $0.43 \pm 0.04 \mathrm{~d}$ & US-EPA [12] & $0.05-0.20$ \\
A3 & $0.19 \pm 0.01 \mathrm{a}$ & European Union [13] & 0.20 \\
A4 & $0.32 \pm 0.02 \mathrm{c}$ & & \\
\hline
\end{tabular}

Results in the same column followed by the same letter does not show significant statistical differences according to Duncan Test at the probability level of $\mathrm{P}<0.05$. "Maximum concentrations permitted are values legislated to drinking water, indicated for human consume.

current and salt concentration).

According to Duncan's Test at the probability level of $\mathrm{P}<0.05$ (ANOVA One-way), all results showed a significant statistical difference. Analysing the obtained values, the A3 sample presented $126 \%$ lower aluminium compared to the A2 sample which had the highest dissolved aluminium content.

Table 2 shows the comparison between the aluminium content obtained for all assays and important international environmental laws: European Union (EU), United State Enyironmental Protection Agency (USEPA) and Brazilian Environmental National Council (CONAMA). Assay A3 was the single treatment which was in agreement with all legislative requirements.

Since the residual aluminium contents in samples A1, A2 and A4 were higher than the maximum permitted in all legislation, tests of efficacy and monitoring were performed only with the A3 sample.

\subsection{Herbicide Degradation}

The chromatograms obtained by HPLC-UV (Figure 3) indicate that the EF process changed the reaction medium (herbicide solution under treatment). The results showed a displacement of the herbicide chromatographic peak and the appearance of bands without defined structure, related to the byproducts generated.

Initially, the chromatographic peak of the herbicide chlorimuron-ethyl was detected at 1.98 min of analysis (retention time). During the electroflotation the time was increased by a few seconds: after 30 and 60 min of the EF running, the retention times were 2.05 and 2.19 min, respectively.

After $60 \mathrm{~min}$, the chromatogram baseline lost stability, with the herbicide peak appearing in the middle of bands without definition. The lack of stability could be related to the amount of byproducts released into the solution from the herbicide molecule and also in addition the dissolved aluminium generated by the passive electrodes. After 60 min of the EF process, a decrease of the chromatographic peak height was observed, suggesting the beginning of herbicide oxidation.

Observing the chromatogram obtained at $180 \mathrm{~min}$, the herbicide peak does not appear or was superimposed on by other bands. The analytical signals were only one band without a defined structure for a chromatographic peak. Due to these non-defined and structured peaks, it was not possible to quantify the concentration of herbicide during the electroflotation.

In order to study the presence of byproducts, their structures and the breaking of chemical bonds, the next section will discuss the results reported on the gas chromatography-mass spectrometry (GC-MS).

\subsection{Degradation Products}

GC-MS indicated that electroflotation, under the conditions used in this study, changed the molecular structure of chlorimuron-ethyl, but was not sufficient to perform the complete oxidation of the herbicide (Figure 4).

Analysing the mass spectra obtained, at $0 \mathrm{~min}$ (before the reaction) it was not possible to detect the herbicide due its volatility. Between 30 and 60 min (Figure 4(a)), mass spectra of a detected ion (m/Z = 399) indicated a breakage of only one chemical bond in the herbicide structure, corresponding to the chlorimuron-ethyl molecule $\left(\mathrm{MM}=414.821 \mathrm{~g} \cdot \mathrm{mol}^{-1}\right)$ lacking one methyl group $\left(\mathrm{MM}=15.034 \mathrm{~g} \cdot \mathrm{mol}^{-1}\right)$.

After $2 \mathrm{~h}$ of reaction, the ion detected (Figure 4(b)) indicated the loss of an additional $14.026 \mathrm{~g} \cdot \mathrm{mol}^{-1}$. Summing these lacking $\cdot$ molecular masses, the value obtained corresponds to an ethyl group $\left(\mathrm{MM}=29.039 \mathrm{~g} \cdot \mathrm{mol}^{-1}\right)$. 

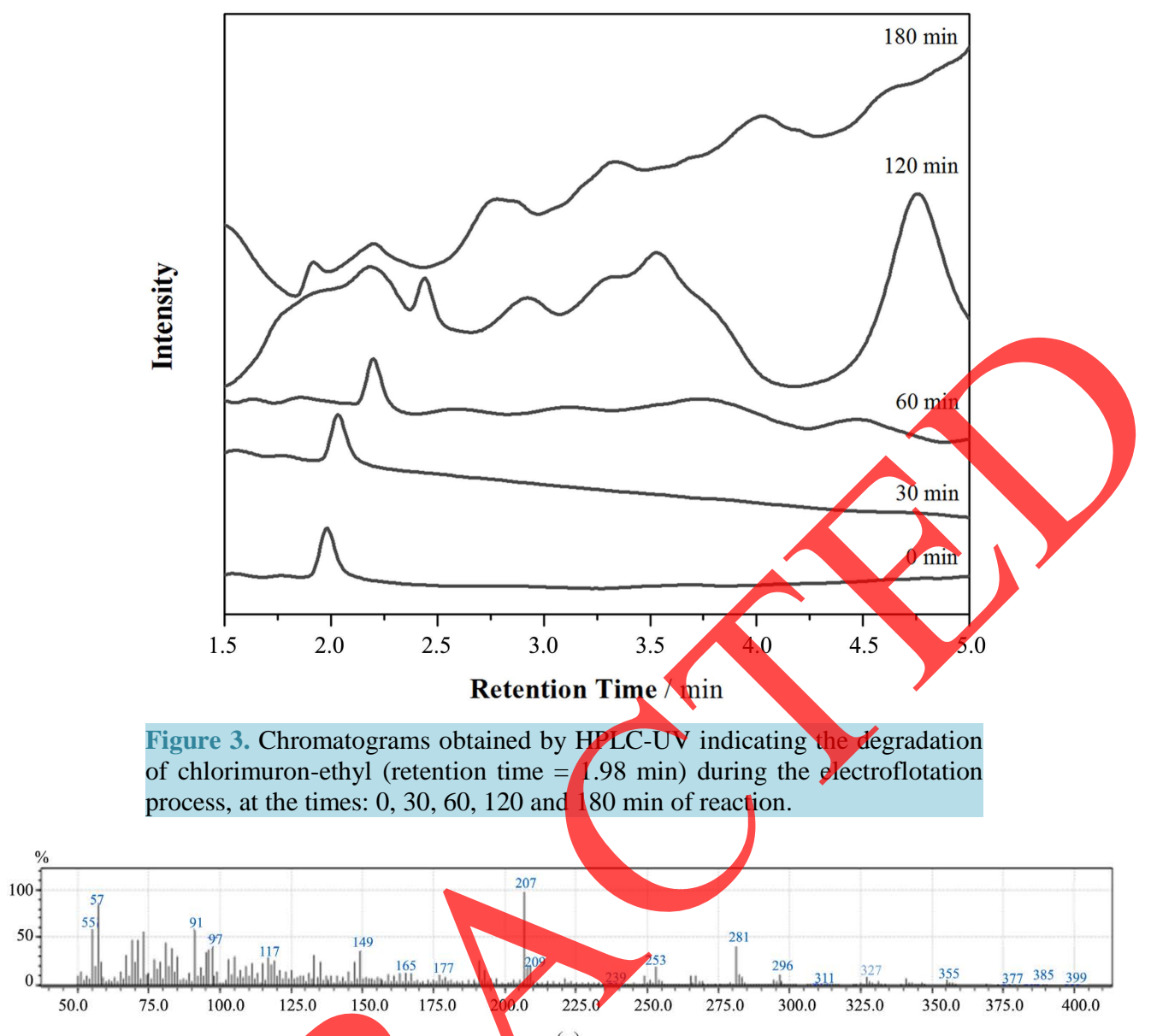

(a)

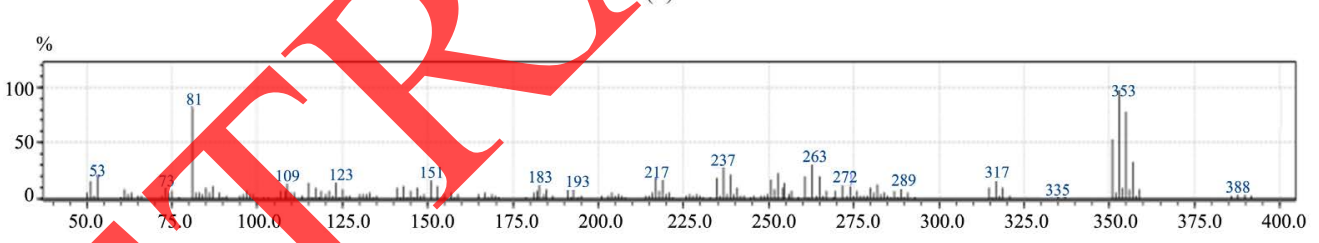

(b)

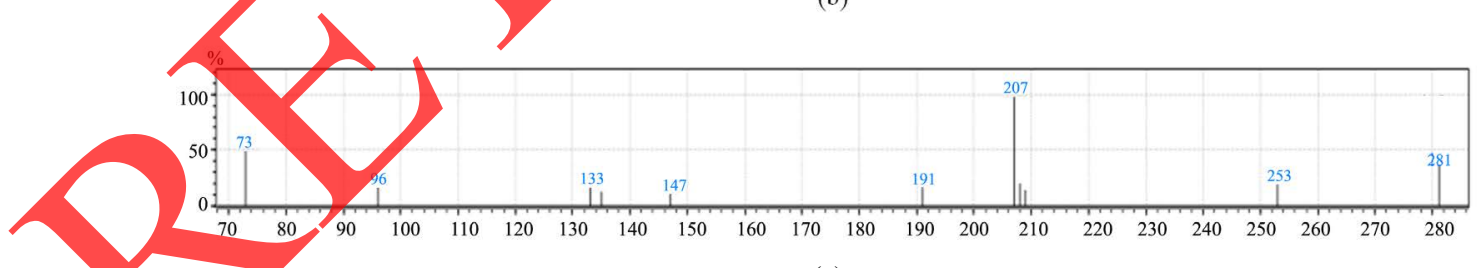

(c)

Figure 4. Mass spectra (MS) obtained by gas chromatograph (GC) during the electroflotation of chlorimuron-ethyl herbicide. (a) Spectrum obtained at $30-60 \mathrm{~min}$, indicating a molecular ion $\mathrm{m} / \mathrm{Z}=399$; (b) Spectrum obtained at 120 min, indicating a molecular ion $\mathrm{m} / \mathrm{Z}=388$; (c) Spectrum obtained at $180 \mathrm{~min}$, indicating a molecular ion $\mathrm{m} / \mathrm{Z}=281$.

At $3 \mathrm{~h}$, the mass spectrum indicated the breakage of a chemical bond in the middle of the molecular structure, separating the urea and sulfonyl groups (Figure 4(c)). Only one fragment was detected $(\mathrm{m} / \mathrm{Z}=281)$ corresponding to the urea group plus a residue of the sulfonyl molecule $\left(\mathrm{SO}_{2}^{-}\right)$.

Based on the results of the mass spectra, a mechanism of degradation is proposed (Figure 5). The small differences between the detected ions and suggested molecules are related with the rearrangements that may occur within the molecule and its byproducts (fragments). 


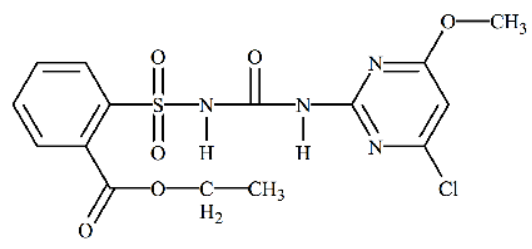

$\mathrm{MM}=414.821 \mathrm{~g} \mathrm{~mol}^{-1}$

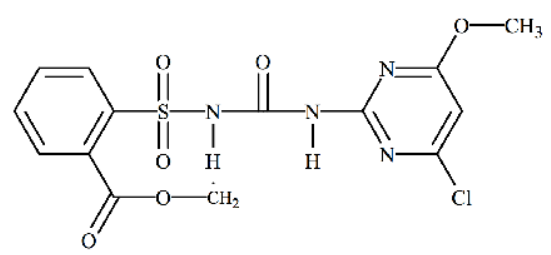

$\mathrm{MM}=399.786 \mathrm{~g} \mathrm{~mol}^{-1}$

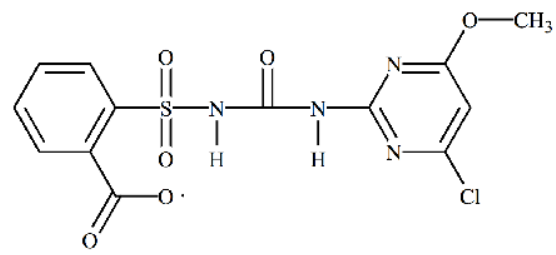

$\mathrm{MM}=385.760 \mathrm{~g} \mathrm{~mol}^{-1}$

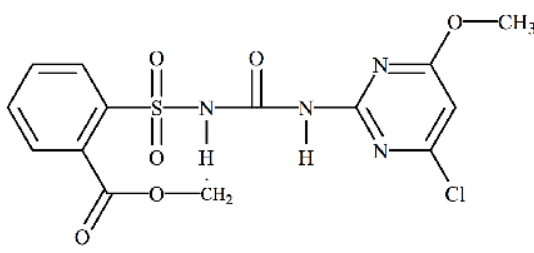

$+\quad \cdot \mathrm{CH}_{3}$

$\mathrm{MM}=399.786 \mathrm{~g} \mathrm{~mol}^{-1}$

$\mathrm{MM}=15.034 \mathrm{~g} \mathrm{~mol}^{-1}$

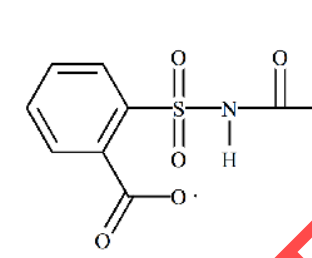

|

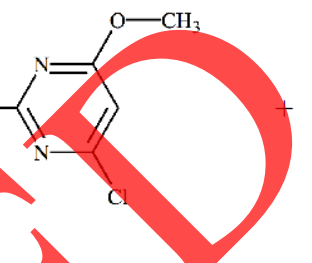

$\mathrm{CH}_{2}$

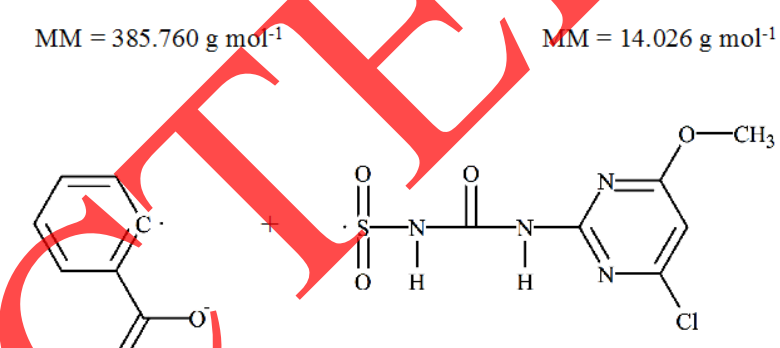

$\mathrm{MM}=120.105 \mathrm{~g} \mathrm{~mol}^{-1}$

Figure 5. Mechanism of degradation proposed to elucidate the chemical reactions which occurred during the electroflotation of chlorimuron-ethyl herbicide.

\section{Conclusions}

The data presented support the following conclusions:

- The study confirms the expectation that electroflotation (EF) can be applied in the treatment of wastewaters containing chlorimuron-ethyl.

- The chromatograns obtained by HPLC-UV indicate that the EF process changed the reaction medium, indicated by the generation of byproducts, observed through the occurrence of chromatographic bands and the loss of chromatogram baseline stability.

- GC-MS indicated that EF was not enough to perform the complete herbicide oxidation. The mechanism of degradation shows that EF broke one of the moieties connected by the sulfonylurea bridge.

- Although the electroflotation was not enough for a complete chlorimuron-ethyl oxidation, in future we intend

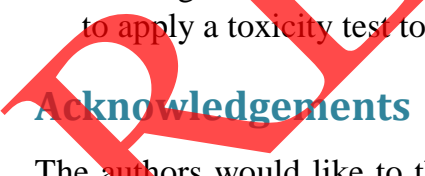

The authors would like to thank the CAPES-MEC, through grants to R. R. Nunes. This research was partially funded by CNPq (process number 306715/2013-9) and CAPES.

\section{References}

[1] Oliveira Jr., R.S., Constantin, J. and Inoue, M.H. (2011) Biologia e manejo de plantas daninhas. Omnipax, Curitiba.

[2] Hay, J. V. (1990) Chemistry of Sulfonylurea Herbicides. Pesticide Science, 29, 247-261. http://dx.doi.org/10.1002/ps.2780290303

[3] Baird, C. (2008) Environmental Chemistry. Freeman, New York.

[4] Lafi, W.K. and Al-Qodah, Z. (2006) Combined Advanced Oxidation and Biological Treatment Processes for the Removal of Pesticides from Aqueous Solutions. Journal of Hazardous Materials, 137, 489-497. 
http://dx.doi.org/10.1016/j.jhazmat.2006.02.027

[5] Palomino Romero, J.A., Salazar-Banda G.R. and Rezende, M.O.O. (2013) Treatment of Sewage by Electroflotation: A Pilot Study. Separation Science and Technology, 48, 192-198. http://dx.doi.org/10.1080/01496395.2012.682616

[6] Crespilho, F.N. and Rezende, M.O.O. (2004) Eletroflotação: Princípios e Aplicações. RiMa, São Carlos.

[7] Langford, T.E.L. (1990) Ecological Effects of Thermal Discharges. Elsevier, New York.

[8] Lanças, F.M. (2009) Cromatografia Liquida Moderna—HPLC/CLAE. RiMa, São Carlos.

[9] Crespilho, F.N., Santana, C.G. and Rezende, M.O.O. (2004) Tratamento de efluentes da indústria de processamento de coco utilizando eletroflotação. Química Nova, 27, 387-392. http://dx.doi.org/10.1590/S0100-40422004000300005

[10] Mansour, L.B. and Ksentini, I. (2008) Treatment of Effluents from Cardboard Industry by Coagulation-Electroflotation. Journal of Hazardous Materials, 153, 1067-1070. http://dx.doi.org/10.1016/j.jhazmat.2007.09.061

[11] CONAMA (2005) Resolução N³5, Brasília.

[12] EPA (2009) EPA 816-F-09-0004-National Secondary Drinking Water Regulations, Washington.

[13] EC (1998) Council Directive 98/83/EC—On the Quality of Water Intended for Hunan Consumption-Official Journal of the European Communities, Brussels.

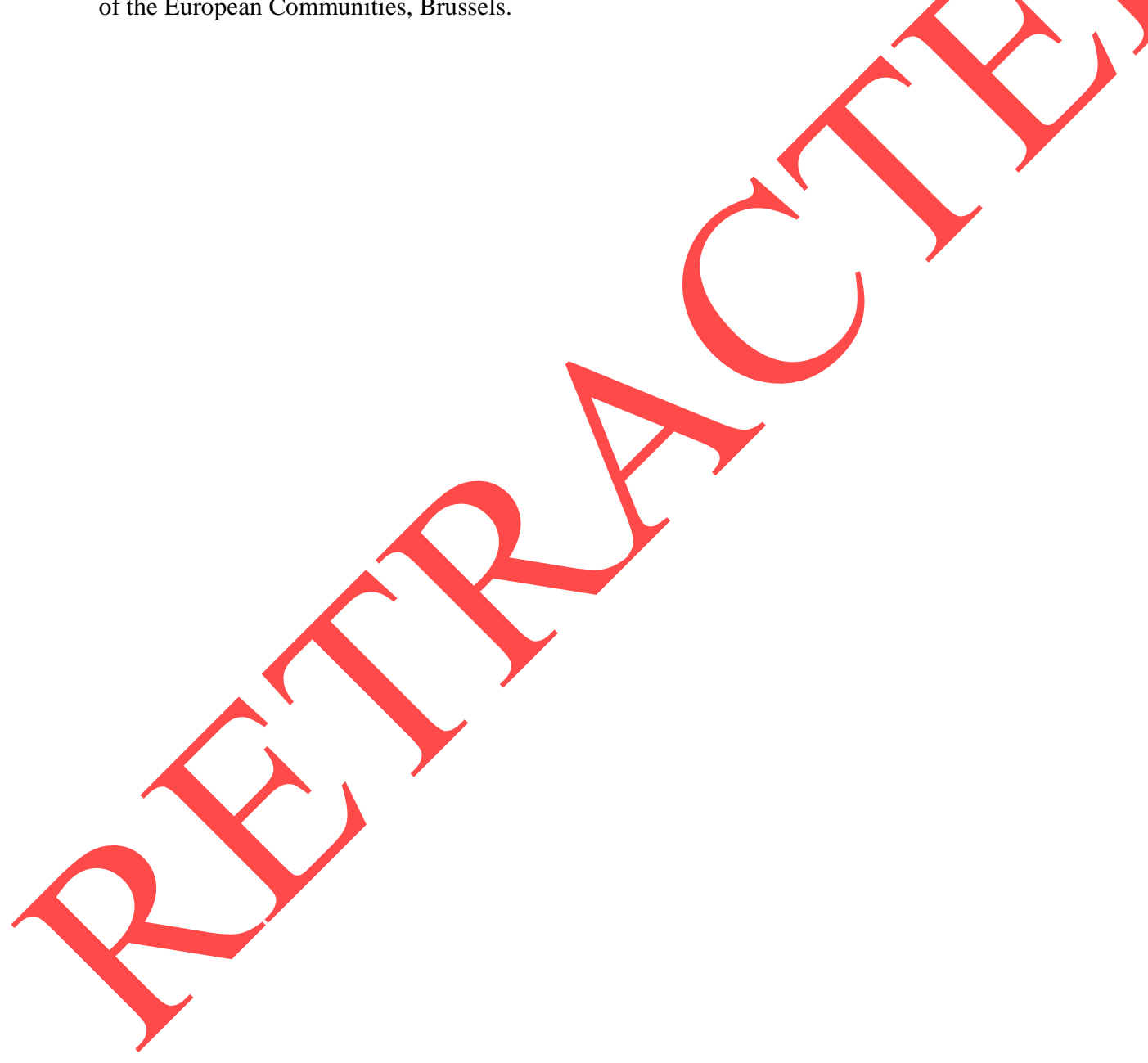

